\title{
ENVIRONMENTAL EDUCATION: THE ROAD TO SUSTAINABILITY
}

\author{
Joziane Mendes do Nascimento \\ Especialista em Auditoria, Perícia e Gestão Ambiental/IPOG - Instituto de Pós-Graduação \\ \jozianemendes@hotmail.com \\ Tainá Pellegrino Martins \\ Observatório Urbano Estado do Rio de Janeiro/UERJ \\ Josimar Ribeiro de Almeida \\ Observatório Urbano Estado do Rio de Janeiro/UERJ
}

\begin{abstract}
Given the seriousness of environmental problems that threaten the human species on the planet, the need for sustainability is one of the imperatives of the present. Its range is up to a challenge and a duty of the State that through public policy, has been seeking to develop environmental awareness and change the attitude of the citizens on the existing natural resources. Many are the environmental and social projects existing in the country that aims to improve the relationship between human and nature. The question is to what extent they contribute to the preservation of the environment and the social development of those involved. In this context, this survey found that "Bairro Beleza" Workshop, "Jovem Cidadão" Project conducted by the Government of the State of Amazonas, has proved efficient. The workshop is presented as tool to fight environmental degradation, therefore, deserves better attention and investment of the government.
\end{abstract}

Keywords: Environmental Education; Environment; Sustainable Development.

\section{EDUCAÇÃO AMBIENTAL: O CAMINHO PARA A SUSTENTABILIDADE}

\section{Resumo}

Tendo em vista a gravidade dos problemas ambientais que ameaçam a espécie humana no planeta, a necessidade de sustentabilidade é um dos imperativos da atualidade. Seu alcance constitui-se um desafio de todos e um dever do Estado, que através de políticas públicas, vem buscando desenvolver a consciência ecológica e a mudança de postura dos cidadãos diante dos recursos naturais existentes. Muitos são os projetos sócios ambientais existentes no país que tem a finalidade de melhorar a relação homem e natureza. Resta saber até que ponto os mesmos contribuem para a preservação do meio ambiente e para o desenvolvimento social dos envolvidos. Nesse contexto, a presente pesquisa constatou que a Oficina Bairro Beleza, do Projeto Jovem Cidadão realizada pelo do Governo do Estado do Amazonas, tem se demonstrado eficiente. A Oficina apresenta-se como ferramenta no combate a degradação ambiental, por isso mesmo, merece uma melhor atenção e investimento do poder público.

Palavras-chave: Educação Ambiental; Meio Ambiente; Desenvolvimento Sustentável.

\section{INTRODUCTION}

Environmental education can be considered a key presupposed for the preservation of the environment and to develop a more responsible society. However, it can not achieve the desired sustainable development without considering man as the agent of transformation. 
The scenario of environmental degradation such as water contamination, the large volume of waste generation, air pollution and global warming, highlights the seriousness of the problem and the size of the challenge which we all have to face to resolve such damage. Also, it was considering their international scopes, since environmental degradation does not obey geographical boundaries, such problems become even more relevant and troubling.

Given this context of pollution, we can not remain indifferent, on the contrary, there is an urgent need for engagement in combating environmental problems through environmental education that awakens an ecological conscience able to promote community development, creating conditions for the preservation of environment, sustainable development and improved quality of life.

And to begin this process, public policy, and social and environmental education projects are presented as an excellent alternative. It is already known that across the country, many studies of this nature have been developed in various nuclei of society.

Therefore, this research brings the discussion to reflect on the efficiency of these socioenvironmental projects to change the current framework of environmental imbalance, taking as a case study of reusable materials "Bairro Beleza" Workshop, the "Jovem Cidadão" Project of the Government of the State of Amazonas.

The research was conducted between April and August, 2011, in fifteen public schools from State system located in six urban areas of Manaus. During the study, were interviewed by means of a form, students from ages twelve to fifteen years, as well as the instructors responsible for conducting the workshop through another form.

Among the aims of the research was sought, mainly, to evaluate the contributions of the workshop of environmental reuse for the environmental preservation and social development of students. And the specific aims, check the environmental awareness in students, to identify sustainable practices performed during participation in the workshop, identify changes in the behavior and attitude of the students after their participation in the activity, diagnose difficulties in conducting the workshop and check the professional qualifications of the staff involved in making the same.

The relevance of the study confirms the importance of environmental education as an agent of transformation of human, the community and the environment. Its consolidation is fundamental to preserving the ecosystem condition, and soon, to ensure the survival of the human species on this planet since, according to Telles $(2004$, p.37) "the use of nature for the benefit of human needs, is a existential imperative that dominates all forms of life, a determinism that threatens the livelihood of other species".

This present research is structured in the form of a scientific paper, containing eminent summary and introduction, that with a dissertative approach distributes seven topics, allowing the reader to conclude that the need to implement more social and environmental projects in the sense of changing the framework of ecological degradation experienced by society, and also to show that education is the most effective tool for that man, through a participatory process, is set as an agent of that change process.

\section{Importance of Environmental Education for Sustainable Development}

The importance of environmental education has been recognized by the most experienced experts in the subject concerned from the understanding that his absence is a cause of degradation is perceived.

Education can be seen as the great hope for the world change. However, education is not an isolated process. It is a participatory process between educated and educating, being necessary to share with others the knowledge, experience and impression. And in this learning process, according to Telles $(2004$, p.70) "is required the interaction between the learner and the 
instructor, and that learning occurs in a totalizing way, it is necessary that the object of learning is known and comprehended by educated and it usually happens when he experiences and interacts with the object". Nevertheless, in a context which the environment is the object of study, we suggest that when the interaction between student and this medium occurs, the assimilation of knowledge becomes more effective.

As Pedrini (1997, p.268) "Environmental education is an individual and collective process." Already pacified between environmentalists and educators is essential that a great effort to arouse interest for individuals with the balance of the planet. And it's not big news to say that the school has an extremely important role in this fight.

The applicability of this long awaited education, however, is no simple task, because its implementation requires well qualified and committed professionals and their target audience is usually the result of a generation devoid of ecological awareness. His practice is too complex and, once the economic model adopted revolves around exacerbated consumerism and enrichment at any price.

Environmental education should be developed in order to produce changes first in man, including his own conduct, in order to protect the natural assets. Because preserve the ecosystem is to preserve life, because all the natural resources that man needs stemming from it. As Barbieri (2007, p.8) says "natural resources are primary or unique assets and services that everyone else depends".

Given the lack of perception of human in relation to environmental issues, many movements have emerged in the past, rising the environmental debate. Among them, the Stockholm Conference, held in Sweden in 1972. At that time 19 countries have signed the UN Declaration on the Human Environment, whose principle 19 says:

\footnotetext{
"It is an indispensable work of education on environmental issues, aimed at both the young generations, as adults, to pay due attention to the less privileged sectors, to lay the foundations of a well-informed public opinion and responsible conduct of individuals, companies and communities, inspired by the sense of responsibility relating to the protection and improvement of the environment in all its human dimension".
}

In 1975, the Belgrade Charter, came to establish goals and objectives to structure a program of environmental education at different levels, it declares that the goal of environmental education should be to develop a conscious and concerned global population with the environment, to act individually and collectively to find solutions to current problems and to prevent new problems. This goal seems to have more and more sense, considering so many environmental disasters that happen in all parts of the world.

The Declaration of the Tbilisi Conference, held in 1977, describes that environmental education should address both the formal and informal education to people of all ages. And also, awakening the individual to actively participate in solving environmental problems of their daily lives. This recommendation is shown, since the eighties, the need to include men in this transformation process of conduct facing ecological issues.

More and more, we realize that local action can actually generate a global impact, as these problems have a global dimension. Therefore, ecological awareness must be performed holistically, participation is required of all: government, business, family, school and society so that everyone take a new conduct faced on the risks that threaten the nature.

There are currently several environmental education projects being conducted throughout the country in order to combat the culture of consumerism and pollution that was rooted from generation to generation and to press the government, which in many places is still silent on this context. However, public policies developed for these purposes are scarce, although emergency and demand for preservation is much greater than the supply of 
environmental education. It is necessary the intervention of the government, since "the failure of environmental policies due in large part to the inability of their governments to set priorities for the various problems and interventions" (ALMEIDA, 2009, p.2).

Therefore, the State must exercise its role as representative of the collective interests through the instruments of their public policy, seeking to offer the citizen access to environmental quality education as a right already established by the Constitution of the country itself, as the art.225, $\S 1$, VI, which declaring as one duties of the government to promote environmental education at all levels of education and public awareness of the preservation of the environment.

Everything must be done in order to attain sustainable development, which can be understood as development that respects the limits of nature and allows future generations to also progress. And among its many challenges, highlights the need to link economic development with environmental preservation. We know that this development will only be possible, since we regain the lost time and this race may not start for another starting point, but through environmental education, since it has been placed as one of the pillars for the realization of a sustainable model.

\section{Identification, purpose and history of the "Jovem Cidadão" Project and "Bairro Beleza" Workshop}

The "Jovem Cidadão" Project created in 2007, and conducted by the Government of the State of Amazonas, is a violence prevention strategy that offers teens and youth activities after school, such as integrated art, culture, education, sport, leisure and qualification professional.

The project is coordinated by the Department of State and Social Care-SEAS and with the participation of several government agencies for their performance, benefiting 93.114 million students 12-20 years of 138 public schools in Manaus and other 75 municipalities of Manacapuru, Maués, Parintins, Tefé, Benjamin Constant, Atalaia do Norte, Itacoatiara and Tabatinga. How many districts are included, and how many students participate and how many people are employed?

The partner government agencies of the State Government acting in the execution of the "Jovem Cidadão" Project are the Secretary of State for Culture-SEC, the State and Youth Department, Sport and Leisure- SEJEL, which serving students aged twelve to fifteen years, and Educational and Technological Amazon Center - CETAM that caters to the age group of sixteen to twenty years.

The SEC offers workshops to students of the environment, theater, dance, music and musical instruments, photography, cinema, visual arts, and digitizing rare books and CETAM enables various types of vocational courses, both methods work on two weekly meetings, while the SEJEL offers sports activities in its various practices operates three times a week. Thus, the student is in school full time, because when he is not participating in the activities offered by the SEC and the CETAM, will be inserted in the sporting activities provided by SEJEL.

The main objective of the Project is to reduce the exposure of young adolescents to violent situations, and thereby contribute to the development of their potential. To achieve this, the project aims to raise school attendance and student achievement and participation in school activities responsible. The student adherence to the project is free and voluntary. And the State Government scholarship grants for money for those who intend to participate in the amount of $\$ 30.00$ reais for families with a part of the project and $\$ 50.00$ reais for families with two or more children. However, to receive the scholarship, the student must earn a minimum rate of $75 \%$, both in school and in the project and approval at the end of each series. 
The research explored the exposed workshop environment called "Bairro Beleza", which is a recreational activity that promotes a participatory process, where the educated takes on the role of central element of the teaching and learning process required, working actively in the diagnosis of environmental problems and finding solutions. The workshop is conducted in 48 public schools in the state education system, covering the six urban areas of the city, with an average of approximately 42 thousand students of age group 12-15 years and is coordinated by the SEC.

The workshop aims to raise environmental awareness of the students about the importance of the contribution of each in sustainable development by promoting the interaction between education and environmental preservation with the use of recyclable materials. It also seeks to develop lines of learning leading to a harmonious relationship with the school environment and the environment, causing the student to have a critical analysis of what has caused the destruction of natural resources and various species.

The activities developed by the "Bairro Beleza" Workshop is practical classes with the use of alternative and used materials, lectures, cleaning and cultivating gardens and flower beds maintained in schools, planting seedlings, distributing baskets selective collection hits on environmental spaces such as zoos, reserves, parks, squares and institutes, ornamentation and decoration of the school environment during Environment Week and the Christmas month, conducting educational acts using distribution of pamphlets, brochures and posters and participation in exhibitions and existing cultural moments in school . During practical classes students use as pet bottle waste, newspapers, magazines, cans and cardboard are recycled and made into utensils and decorative objects. Thus "Bairro Beleza" acts in preserving the environment in a fun way, turning "Garbage in Art".

In addition, throughout the year, students work in various outdoor activities, including participation in government campaigns, cultural performances as Amazonas Film Festival in events like holidays and Christmas Concert, now having also participated in recordings for programs national television as the "Caldeirão do Huck".

\section{METHODOLOGY}

The survey was conducted with the use of methods, and as Marconi and Lakatos (2002) points out, the method is a set of systematic and rational activities more safely and economy will achieve the goal, tracing the path to be followed by detecting errors and helping at decisions of the scientist.

Regarding the nature search characterized qualitative because sought to evaluate the benefits of the activity of environmental reuse the "Jovem Cidadão" Project to both the environment and for the individual. According to Gonsalves (2003), qualitative research is concerned with understanding and the interpretation of the phenomenon, considering the meaning that others give to their practices, which requires the researcher to a hermeneutic approach.

As for research purposes was characterized as exploratory, since at first sought to become familiar with the problem and finding information. As Gil (2010, p. 27), exploratory research aims to provide greater awareness of the problem in order to make it more explicit or build hypotheses.

As for the type, the research was characterized as research literature, documentary character and field. Bibliographic needed because systematic theoretical foundation based on material already published as books, journals, and electronic network, not limited to the single copy of ideas and opinions, but having the particularity research in locus, analysis and interpretation of the facts. And according to Vergara (2005, p. 48), the literature is a study developed based on materials published in books, magazines, newspapers, electronic network, 
i.e. material accessible to the general public. Documentary, as electronic documents and files that provided information on the "Jovem Cidadão" Project and Environmental Reuse Workshop, thus giving a better understanding for the comprehension to work on projectrelated schools were used. According to Gil (2010, p. 31), is considered the source document when the material consulted is internal to the organization. Also characterized as field research, because data in schools where activities are performed were collected. And according to Vergara (2005, p. 48), field research consists on empirical investigations conducted at the site where it occurs or has occurred or a fact or phenomenon has explanatory material, including interviews, questionnaires, testing and participative observations or not.

The research population comprised the workshop of Environmental Reuse and "Jovem Cidadão" Project. According to Gonsalves (2003, p. 67) the population comprised where a study of a particular case, a meaningful unit, considered enough for the analysis of a phenomenon will take place. And the sample consisted of thirty per cent of schools engaged in the workshops. A total of forty-eight schools, within fifteen schools were visited in six urban areas of Manaus. In each school were interviewed thirty percent of the students present at the interview, which corresponded to a total of 71 students interviewed during the survey. During visits also thirteen instructors of the workshop were interviewed. The sample, as Marconi and Lakatos (2002) is a representative part of the population.

Data collection and the interview form were used as instruments. We developed two forms, one directed to professionals in the environmental workshop with five closed and two open questions and other questions directed to students with four closed questions and three open questions. Both were filled with the help of interviews, which were conducted by the author of this research. Based on Cervo, Bervian and Da Silva (2011, p.51-53), form is an informal list, for the collection of data derived either from observations or questions, and its filling is made by the investigator himself, and the interview is a directed to a defined target whereby a party collects, by means of interrogation data for the search conversation.

\section{Search results with students from "Bairro Beleza" Workshop}

During the development of the survey, respondents were seventy-one students who provided important information on various aspects. The contact with them allowed to realize that for many, the project provides an opportunity for citizenship and social inclusion, and more than that, it also represents the possibility of influencing and changing the reality of the context in which they are inserted. The contribution of the workshop for the environment and the social development of those involved have been confirmed and will be reported in the next topics.

\section{Reasons for the participation in the workshop}

When asked about the main reason that influenced to participate in the environment reuse "Bairro Beleza" workshop, it was observed that the interest in learning emerges as the main reason, correspond 54\%. Is possible to perceive in many, the joy of having the opportunity to be part of the project, leaving the idle hand, developing skills, expanding the circle of friends in a dynamic way without paying anything for it and may even receive a scholarship that helps us costs with pleasure. 
Table 1. Motif that led the students to participate in the Workshop

\begin{tabular}{|l|c|c|}
\hline \multicolumn{1}{|c|}{ Answer } & Amount & Percentage \\
\hline Interest in learning & 38 & $54 \%$ \\
\hline Idle time & 10 & $14 \%$ \\
\hline Curiosity & 9 & $13 \%$ \\
\hline Interest in developing skill & 7 & $10 \%$ \\
\hline $\begin{array}{l}\text { Need to expand the cycle of } \\
\text { friendship/interaction/ fun }\end{array}$ & 6 & $8 \%$ \\
\hline Other Total & 1 & $1 \%$ \\
\hline \multicolumn{1}{c|}{ T1 } \\
\hline
\end{tabular}

Source: Data produced by the survey (2011)

\section{The occupation before the participation in the workshop}

It was found that before attending the workshop, students occupied the time in many different forms, and $44 \%$ reported that they did helping with household chores and $18 \%$ who said that once occupied the time attending courses.

It was curious to note that the courses in which these $18 \%$ participated correspond to other types of activity offered by the "Jovem Cidadão" Project. At the time of the conversation the students justified the exchange of course saying that decided to migrate to reuse environmental "Bairro Beleza" workshop by affinity issues.

All demonstrated satisfaction in being able to occupy their time more fun and interesting way. This finding demonstrates the importance of implementing more projects of this nature throughout the country, as well as greater coverage of public policies in this regard, it seems the need to involve adolescents and youth in the teaching-learning process.

Table 2. Occupation of students before attending theBairro Beleza Workshop

\begin{tabular}{|c|c|c|}
\hline Answer & Amount & Percentage \\
\hline $\begin{array}{l}\text { Helped with household } \\
\text { chores }\end{array}$ & 31 & $44 \%$ \\
\hline Watched TV & 13 & $18 \%$ \\
\hline Participated in course(s) & 13 & $18 \%$ \\
\hline Slept & 6 & $9 \%$ \\
\hline Played at home & 4 & $6 \%$ \\
\hline Played sports & 3 & $4 \%$ \\
\hline Played on the street & 1 & $1 \%$ \\
\hline Total & 71 & $100 \%$ \\
\hline
\end{tabular}

Source: Data produced by the survey (2011)

\section{Student learning in relation to the environment}

We seek to raise what the students have learned in relation to the environment and occasion, all showed some type of knowledge acquired. Among the various answers, we highlight the learning reusing waste, which previously were discarded and turning them into useful objects and awareness to preserve the environment, not committing wrong acts such as littering and rivers. It was found in some students concern for the preservation and planting of tree seedlings, with the availability of teaching others to preserve and maintain the clean environment. There were some who recognized that before participating in the project 
committed no ecological acts such as littering. Others have shown concern about the need for preservation, emphasizing the dependence of man in relation to nature and its fruits.

\section{Suggestions from students to better performing activities}

During the interviews, students had the opportunity to make suggestions for better progress of the workshop activities, among which we highlight the need for greater availability of consumables by the State Government, as sometimes students are idle or are driven to perform other work, due to lack of equipment necessary to the ongoing activities. The second most recurrent suggestion is related to the need for a more appropriate place for carrying out the activities: a room with refrigeration, decoration, space, tables, chairs and sufficient to meet the demand of student's cabinets, since virtually none of the schools has a room with these characteristics. There are complaints about the noise, space, heat, considering that in almost all schools and centers visited, the space provided for the "Bairro Beleza" is usually the hallway or the cafeteria. There are factors that in one way or another affect the quality of learning. There was also a portion of respondents, not exceeding $5 \%$, which stated that everything is great and they had no suggestions to offer.

It was noticed that there are many structural setbacks to be overcome, so that the suggestions are met and that the conditions for carrying out the activity become more favorable.

\section{The preference of the students regarding the activities performed in the workshop}

Students of activity "Bairro Beleza" perform various theoretical and practical activities. However, the main activity is the manufacture of utensils and objects with reusable materials. And research has shown that of all the activities, this is also the favorite of $69 \%$ of the students interviewed.

Table 3. Preference students regarding the performed activities Office

\begin{tabular}{|l|c|c|}
\hline \multicolumn{1}{|c|}{ Answer } & Amount & Percentage \\
\hline Reuse of materials & 49 & $69 \%$ \\
\hline Interaction with other students & 14 & $6 \%$ \\
\hline $\begin{array}{l}\text { Planting seedlings / make gardens } \\
\text { / garden clean up }\end{array}$ & 4 & $3 \%$ \\
\hline $\begin{array}{l}\text { Develop and practice selective } \\
\text { gathering }\end{array}$ & 2 & $1 \%$ \\
\hline Educational acts/flyers / brochures & 1 & $1 \%$ \\
\hline Know conservation areas & 1 & \\
\hline Source: Data produced by the survey & $2011)$ & \\
\hline
\end{tabular}

Source: Data produced by the survey (2011)

\section{Changes and/ or improvements in the lives of students after participation in the workshop}

All students recognize changes and/ or improvements in their lives after they began participating in the Workshop. The majority emphasized the behavior and the best time employment as major changes. They said they were previously too unruly, inattentive or shy and that in the course of activities adopted better behavior through treating people better, developed the patience, attention, creativity and interpersonal skills and confessed that before the workshop did not have such interesting things to do. Learning regarding the importance of 
preserving the environment was also mentioned quite as well as improvements related to studies, more specifically, to study the discipline of arts in school. Others spoke of the importance of the scholarship amount received monthly, explaining that the money many times help meet the basic needs like food and leisure. Some have said, including that gained new friends and that life has become more fun.

\section{The use of learning}

It was observed that all students are practicing beyond the workshop, which has been taught in class. Whereas 35\% reported that they also make objects and utensils with reused materials at school or at home. It is interesting to find that $33 \%$ of students teach others to do the objects. In addition, a further $11 \%$ said they teach others to preserve the environment, which most often are family members, neighbors and colleagues of the school.

It appears that the knowledge gained has been perfected and passed on to others. The learning has been used for the purpose to which it is proposed, which is to transform students into agents of change. Many stated that the readymade objects attract the attention and curiosity of people around him and from that the students have the opportunity to disseminate that there are better ways to allocate certain types of waste.

Table 4. How students have practiced learning outside the workshop.

\begin{tabular}{|l|c|c|}
\hline \multicolumn{1}{|c|}{ Answer } & Amount & Percentage \\
\hline $\begin{array}{l}\text { Making objects reused in school or at } \\
\text { home }\end{array}$ & 25 & $35 \%$ \\
\hline Teaching others to do the objects & 23 & $33 \%$ \\
\hline Presenting people with reused objects & 15 & $21 \%$ \\
\hline $\begin{array}{l}\text { Teaching others to preserve the } \\
\text { environment }\end{array}$ & 8 & $11 \%$ \\
\hline
\end{tabular}

Source: Data produced by the survey (2011)

\section{Search results with the Professional "Bairro Beleza" Workshop}

Information obtained during the interviews with the responsible professionals for conducting the environmental reuse activities showed that there is professional training of those involved and that they have some kind of experience related to the environmental field. It was also observed that instructors perceive changes with regard to the social development of students. They had the chance to make suggestions for the best performance of activities of the workshop. All these data are reported below.

\section{The level of education}

Of the professionals interviewed, $85 \%$ are hired as instructors and $15 \%$ still work as interns. And $54 \%$ have a university academic education, $31 \%$ have incomplete higher education and $15 \%$ are trainees who do not have higher academic education.

\section{Academic training related to the field of education, environmental or social}

Of the thirteen professionals surveyed, $85 \%$ have academic training courses related to educational, environmental and social areas. Emphasizing courses in Biology, Tourism, Pedagogy and Environmental Management. The other $15 \%$ is for trainees who have only a high school education. 


\section{Participation in courses, lectures and seminars related to the environmental area}

All reported having courses, lectures and/ or seminars related to environmental issues. Among which stand out environmental education courses and lectures about sustainable development.

It is noteworthy that before starting activities with students, instructors attend a twoday workshop receiving guidance related to the design and development of practice of reusing materials.

\section{The professional experience related to the educational field, environmental or social}

Regarding professional experience, $46 \%$ work in the area for over a year, $31 \%$ of professionals for almost a year, and $23 \%$ worked for more than two years.

\section{The opportunity to have been a trainee at the project before becoming instructor}

It was found that $54 \%$ of the professionals have been hired as instructor was trainees environmental reuse workshop before they become employees. This information demonstrates the importance of the project with regard to employment opportunities, considering that everyone has the opportunity to employability in the future.

\section{Changes and/ or improvements noted in students after their participation in the workshop.}

When they were asked what they think has changed and/ or improved the lives of students after they began to participate in the activity "Bairro Beleza", instructors showed changes related to environmental awareness, learning to work with the production of objects from the use of reused and behavior, since most of the students had a very unruly or shy profile, which ended up changing the course of interaction with the workshop, since the activity develops interaction, concentration, discipline and creativity.

\section{Suggestions from teachers to better performing activities}

The improvements suggested by instructors coincide with those made by students. It was confirmed the need for a more appropriate place for carrying out the activities and bigger and better availability of consumables, since there are delays in delivery of materials by the State Government, or, are not enough to attend the need of the activities, which leads to the lack of material, forcing teachers to make use of improvisation so that students are not left without class.

\section{CONCLUSION}

The contributions of environmental reuse workshop of the "Jovem Cidadão" Project for the environment and social development of the student are many and significant. The activity is an example of public policy that has benefited everyone involved.

For the environment we were able to verify contributions related to the change of posture to existing environmental problems and the learning and development of ecological awareness of students, many of whom already act as multipliers of knowledge acquired. It was also observed that the vast majority have pleasure in activities and various sustainable 
practices are held throughout the year. All students are putting into practice the learning, either through actions such as: teaching others to do the utensils and objects with reused material is gifting family and friends with them.

As for the social development of students, both in their vision for the teachers, it has been improvements in behavior, highlighting the development of patience, creativity, attention and discipline, loss of shyness and better social relationships with peers and family. It also observed improvements related to best time employment and studies from the guidance received by the instructors of the project.

It was found that despite the instructors are qualified to work in the workshop and demonstrate environmental awareness necessary to education, there is a need for greater investment in recycling knowledge of these professionals in order to improve performance and enhance the pedagogical approach of the instructors ecological regarding. Despite, there is a need to expand the approach to environmental issues within the workshop in addition to making objects reused, given that many are facing ecological problems. It is worth taking advantage of the opportunity to connect with these teens for environmental education more critical and thorough discussing issues such as pollution and waste of water, the protection of fauna and flora and the efficient practice of selective gathering.

Regarding the suggestions, both in view of teachers as the students, the government should continue investing in infrastructure, since the absence of more appropriate place to practice the activities and gaps in the availability of consumer material constitute the biggest complaints of respondents.

The results confirm that education really is the way to any change. And this process should also give the school, since it also plays an important role in building knowledge.

Galbraith once said that with education and only with it, the improvement comes; without it there is no improvement. (Galbraith cited Barbosa 2008, p.28).

Environmental education of individuals is presented as a strategy to trigger the process of change that scenario.

But there is still a lot to do in the environmental education. Here is a fight that is just beginning.

\section{REFERENCES}

ALMEIDA, Josimar Ribeiro de. Gestão ambiental para o desenvolvimento sustentável. Rio de Janeiro:Thex, 2009 .

BARBIERI, José Carlos. Gestão ambiental empresarial: conceitos, modelos e instrumentos. $2^{a}$ ed.São Paulo: Saraiva, 2007.

BARBOSA, Walmir de Albuquerque. Políticas Públicas e Educação.Manaus:UEA Edições/Editora Valer, 2008.

CERVO, Amado Luiz; BERVIAN, Pedro Alcino; SILVA, Roberto da. Metodologia científica. $6^{\mathrm{a}}$ ed. São Paulo: Pearson Prentice Hall, 2007.

FURASTÉ, Pedro Augusto. Normas Técnicas para o Trabalho Científico, que todo mundo pode saber, inclusive você: Explicitaçãodas Normas da ABNT. 6 ${ }^{a}$ ed . Porto Alegre:s.n., 1998.

GIL, Antonio Carlos. Como elaborar projetos de pesquisa. 5a ed. São Paulo: Atlas, 2010.

GONSALVES, Elisa Pereira. Iniciação à Pesquisa Cientifica. 3. Ed. São Paulo: Alínea, 2003. 
GOVERNO DO ESTADO DO AMAZONAS.Disponível em http://www.amazonas.am.gov.br/noticia acessado em 22 de julho de 2011.

GUIMARÃES, Mauro. Educação Ambiental: No concenso um embate? Campinas, SP: Papirus, 2000.

PÁDUA, José Augusto,organizador.Desenvolvimento, justiça e meio ambiente. Belo Horizonte: Editora UFMG; São Paulo:Peirópolis, 2009.

PEDRINI, Alexandre de Gusmão, organizador. Educação Ambiental: reflexões e práticas contemporâneas. Petropólis, RJ: Vozez, 1997.

TELLES, Tenório; BRAGA, Celdo.Meio Ambiente: educação e qualidade de vida.Manaus:Edições Kintaw, 2004.

VERGARA, Sylvia Constant. Projetos e relatórios de pesquisa em administração .São Paulo: Atlas, 2005. 


\section{APPENDIX I \\ FORM TO THE STUDENTS}

\section{“JOVEM CIDADÃO" PROJECT- "BAIRRO BELEZA" WORKSHOP}

Public School:

Adress:

Name:

Age:

Sex:

Year:

Time of workshop:

Instructor:

1. What was the maily reason that influenced to participate of the environmental education and reuse "Bairro Beleza" workshop from "Jovem Cidadão" Project?

$\square$ Interest in learning

$\square$ Curiosity

Idle time

Interest in developing skill

$\square$ Need to expand the cycle of

$\square$ Receipt of schoolarship

friendship/ interactio/ fun

Other.

2. Before attending the workshop, what did you do this time?

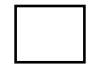

Played at home

$\square$ Played on the street

$\square \quad$ Played sports

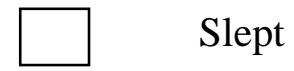

Watched TV

Helped with household chores

\section{Participated in course(s)}

3. What you have learned about environment? 
4.What do you think that should change and/or improve in the "Bairro Beleza" workshop?

5. What do you enjoy most about the "Bairro Beleza" workshop?

Know conservation areas

$\square$ Interaction with other students
clean up

Reuse of materials

Other.
Educational acts / flyers / brochures

Planting seedlings / make gardens / garden

Develop and practice selective gathering

6. What do you think has changed and / or improved in your life after you began participating in the "Bairro Beleza" workshop?

7. How have you put into practice the learning that has acquired "Bairro Beleza" workshop?

Presenting people with reused objects

Teaching others to do the objects

Teaching others to preserve the environment

Making objects reused in school or at home

Marketing reused objects

Interning/ working in the area

COMMENTS: 


\section{APPENDIX I \\ FORM TO THE PROFESSIONALS}

“JOVEM CIDADÃO” PROJECT - BAIRRO BELEZA “WORKSHOP

Public School:

Adress:

Name:

Age:

Sex: Year:

Time of workshop:

1.What is your education level?

$\square$ Basic Education

$\square$ High School

$\square$ Technical education

$\square$ Incomplete higher education

$\square$ Complete higher education

2. Have you academic training related to educational, environmental, or social work?

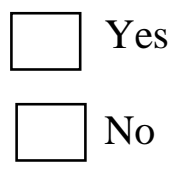

3. Have you courses, lectures or seminars related to educational issue, environmental or social?

$\square$ Yes

$\square$ No

If yes, what? 
4. How long you work in education, environmental or social?

$\square 0$ to 1 year

From 1 to 2 years

From 2 to 4 years

More than 5 years

5. Were you a student/ intern "Jovem Cidadão" Project?

$\longrightarrow$ Yes

$\square$ No

6. What do you think that has changed and/ or improved the lives of students after they began to participate in the "Bairro Beleza" workshop?

7. What do you think should change and / or improve in the "Bairro Beleza" workshop?

COMMENTS: 